УДК 663.18:665.3

\title{
Feedstocks, Methods \\ and Perspectives \\ of Biodiesel Production
}

\author{
Anna Yu. Kuchkina ${ }^{a}$ and Nadezhda N. Sushchik, ${ }^{a, b *}$ \\ ${ }^{a}$ Siberian Federal University \\ 79 Svobodny, Krasnoyarsk, 660041, Russia \\ ${ }^{b}$ Institute of Biophysics $S B$ RAS \\ 50 Akademgorodok, Krasnoyarsk, 660036, Russia
}

Received 24.11.2013, received in revised form 15.01.2014, accepted 23.01.2014

Backgrounds, stages of development and contemporary achievements of bioenergetics are considered in the review. We focus on production of biodiesel which is renewable, ecological safety fuel for transport and an alternative for petrodiesel. Main feedstocks, technological stages of biodiesel production and their effect on fuel properties were concerned. Economical, ecological and energetic problems related with biodiesel production from various bioresources were analysed. As shown, at present the most part of biodiesel in the world is produced from agricultural crop oils. High cost and negative ecological and economical consequences of use of agricultural crops as the feedstock resulted in development of production of "advanced" biofuel, i.e., that based on biomass of microorganisms and various biowastes. However, growth and treatment of microalgae biomass for biodiesel production are still costly and unsustainable. Different ways for improving of such biodiesel cost are supposed, e.g. integrated microbial processes for biofuel and high value-added products or simultaneous wastewater treatment. Production of biodiesel from feedstocks which are various biowastes (for instance, municipal sewage sludges, or bottom sediments dredged from recovered eutrophic water bodies) appeared to be the most economically profitable since such feedstock is cost-free and an important ecological issue of utilization of such wastes is resolved.

Keywords: biodiesel fuel, feedstocks, production stages, fuel properties, cost, biowastes.

\footnotetext{
(C) Siberian Federal University. All rights reserved

* Corresponding author E-mail address: labehe@ibp.ru
} 


\title{
Источники сырья, методы \\ и перспективы получения \\ биодизельного топлива
}

\author{
А.Ю. Кучкина ${ }^{\mathbf{a}}$ Н.Н. Сущик \\ ${ }^{a}$ Сибирский федеральный университет \\ Россия, 660041, Красноярск, пр. Свободный, 79 \\ ${ }^{6}$ Институт биофизики СО РАН \\ Россия, 660036, Красноярск, Академгородок, 50
}

\begin{abstract}
Изложены предпосылки возникновения и последние достижения биоэнергетики получения и использования биодизеля - транспортного топлива, альтернативного нефтяному дизелю. Рассмотрены сырьевые источники для производства биодизельного топлива, основнье технологические этапы и особенности переработки различных видов сырья, их влияние на эксплуатационныехарактеристики биодизеля. Показано, что внастоящее время сырьемдля основной части производимого биодизеля являются масла сельскохозяйственных растений. Данное сырье считается бесперспективным вследствие высокой стоимости и негативных экономических и экологических последствий его использования. Предложено получение биодизеля из непищевого сырья, т.е. различных отходов либо биомассы микроорганизмов. Получение и переработка биомассы микроводорослей в биодизель остаются дорогостоящим и нерентабельным процессом, хотя разрабатываются технологические и экономические способы снижения его стоимости. Производство биодизеля из сырья, являющегося различными видами отходов (например, осадки канализационных очистных предприятий, донные иль, извлекаемые из водоемов при восстановлении качества воды), представляется наиболее экономически выгодным, поскольку затраты на производство такого сырья отсутствуют и происходит частичная утилизация используемых отходов.
\end{abstract}

Ключевые слова: биодизельное топливо, сырьевые источники, этапы переработки, эксплуатационные характеристики, стоимость, отходы производств.

\section{Введение}

В конце XX в. человечество осознало необходимость поиска возобновляемых источников сырья для производства топлива, альтернативного ископаемому. Это обусловило появление и развитие новой научной области - биоэнергетики, направленной на разработку способов получения возобновляемой и экологически безопасной энергии (Tracking Clean Energy Progress, 2013).
Согласно оценкам экспертов, запасы нефти истощаются и будут исчерпаны в течение 50-100 лет при современных объемах потребления (Huang et al., 2010), что вынуждает искать возобновляемые источники энергии. Следствием возрастающего использования ископаемых видов топлива выступает загрязнение окружающей среды. Известно, что во многих городах мира автотранспорт - самый крупный источник загрязнения (Булаткин, 
2009). В составе выхлопных газов, образующихся при сгорании нефтепродуктов, содержится более 300 соединений, наносящих вред окружающей среде: углеводороды, оксиды углерода, азота, серы и др. (Феофилова и др., 2010). Интенсивное использование ископаемого топлива привело к заметным изменениям в глобальном цикле углерода, а именно к резкому увеличению эмиссии техногенного углекислого газа, что может быть причиной роста температуры атмосферы.

Создание различных видов биотоплива, т.е. возобновляемых и экологически безопасных энергоносителей, - один из путей решения вышеназванных проблем (Моисеев, 2011). Использование энергии биомассы позволит существенно снизить загрязнение атмосферы. Согласно некоторым расчетам, замена традиционных источников энергии на энергию, получаемую из биомассы, приведет к 90-95\%-ному уменьшению содержания вредных химических веществ в воздухе (Gerpen, 2005; Huang et al., 2010). Предполагается, что использование биотоплива вместо ископаемых видов топлива также приведет к существенному уменьшению (до $78 \%$ ) техногенной эмиссии углекислого газа в атмосферу (Gerpen, 2005; Huang et al., 2010).

Таким образом, одной из центральных задач XXI в. является замена исчерпаемых и наносящих вред окружающей среде первичных энергоресурсов (газ, нефть, уголь) на возобновляемые и экологически чистые источники (энергия биомассы, рек, ветра, солнца и т.п.). Цель настоящего обзора - изложить предпосылки возникновения и последние достижения биоэнергетики получения биодизельного топлива. Анализ стоящих перед исследователями проблем и вызовов в области производства биодизельного топлива позволяет, на наш взгляд, определить пути дальнейшего развития этого перспективного направления биоэнергетики.

\section{Биомасса как источник биотоплива}

Биомасса и различные биологические отходы, издавна использовавшиеся человеком для получения энергии, в настоящее время обеспечивают лишь около $10 \%$ глобального потребления энергии (REN21, 2013). Это объясняется тем, что биомасса в традиционном виде - малоэффективный источник энергии. С другой стороны, возрастает значение возобновляемых источников, обеспечивающих сейчас около $9 \%$ общемирового энергопотребления. Одним из таких видов энергии является биотопливо, производимое путем высокотехнологичной переработки растительной, животной или микробной биомассы и биологических отходов химическими и биологическими методами. Хотя биотопливо обеспечивает пока около 1 \% мировых энергетических потребностей, согласно прогнозам экспертных международных организаций, его значение в ближайшие десятилетия будет увеличиваться (REN21, 2013; Tracking Clean Energy Progress, 2013). Очевидно, что прирост производства и потребления современных видов биотоплива должен основываться на развитии соответствующих биотехнологий и оценке их экологической значимости.

\section{Твердое биотопливо}

В настоящее время используют как газообразные, так и жидкие и твердые виды биотоплива.

Древнейшим видом твердого биотоплива является биомасса древесных растений, которая и теперь продолжает использоваться в качестве источника энергии. Во второй половине $\mathrm{XX}$ в. было предложено применять 
в качестве топлива отходы лесоперерабатывающих и сельскохозяйственных производств: началось производство топливных гранул - пеллет (REN21, 2013). Пеллеты представляют собой продукт таблетирования древесины, торфа или растительных отходов, таких как древесные опилки, стружки, щепа, шелуха и стебли злаковых культур и т.д. Процесс изготовления включает сушку, измельчение и прессование исходного сырья с последующим охлаждением и повторной сушкой (Larsson et al., 2008). По сравнению с традиционным древесным топливом пеллеты обладают рядом преимуществ: отличаются высокой теплотворной способностью, менее подвержены самовоспламенению, компактны. Разработаны топочные устройства с автоматизированной загрузкой пеллет.

Наряду с перечисленными технологическими преимуществами пеллеты являются экологически чистым топливом. При их сжигании в атмосферу выделяется ровно столько углекислого газа, сколько было поглощено растением во время роста, что позволяет сохранять естественный баланс цикла углерода. При сгорании такого топлива образуется лишь 1-3 \% золы (от исходной массы топлива), что в несколько раз ниже, чем при сгорании угля. Производство пеллет позволяет решить проблему утилизации отходов сельскохозяйственной и деревоперерабатывающей отраслей.

Пеллеты широко применяются преимущественно в европейских странах в качестве топлива в энергетических установках коммунально-бытового и производственного назначения, тепловых и электрических станций, в домашнем хозяйстве (REN21, 2013). Доля российского производства древесных пеллет составляет около 1/20 части от общемирового.

\section{Газообразное биотопливо}

Газообразное биотопливо, или биогаз, получают путем переработки биомассы или органических отходов консорциумом микроорганизмов в анаэробных условиях. Биогаз представляет собой смесь метана (40-70\%), диоксида углерода и незначительных примесей водорода, сероводорода и других газов (Walekhwa et al., 2009). Микроорганизмы могут синтезировать биогаз, используя практически все классы органических соединений, что позволяет применять в качестве исходного сырья коммунально-бытовые, сельскохозяйственные и промышленные отходы (Demirbas, 2008). Таким образом, сырьевые ресурсы для получения биогаза достаточно велики.

Производство биогаза из органических отходов дает возможность решить ряд важных экологических проблем. Ежегодно в результате естественного разложения различных органических отходов и мусора в атмосферу выделяется 590-800 млн т метана, что усиливает “парниковый эффект” (Bond, Templeton, 2011). Поскольку метан обладает существенно большей способностью поглощать инфракрасное излучение, чем углекислый газ, его вклад в повышение температуры атмосферы может сравняться с таковым диоксида углерода, если его выделение будет расти (Джирард, 2008). Большинство стандартных методов переработки и утилизации органических отходов, т.е. различные комбинации прессования, захоронения, естественной биодеструкции и (или) сжигания, приводят к выделению метана в атмосферу. Контролируемое микробное разложение органических отходов, включающее сбор образующегося биогаза, позволит снизить антропогенную эмиссию метана, а также частично переработать используемые отходы в органическое удобрение (Bond, Templeton, 2011). 
Значительное внимание в мире уделяется также водородной энергетике. Водород является экологически чистым (при сгорании образуется лишь вода) и высококалорийным топливом по сравнению с ископаемыми видами. Однако традиционный способ получения водородного топлива (термохимическая переработка ископаемого топлива) не соответствует современным требованиям экологической безопасности (Show et al., 2011). В связи с этим интенсивно разрабатываются технологии получения биоводорода. Биоводород получают при культивировании некоторых видов микроводорослей на органических отходах, богатых углеводами (Zheng et al., 2010; Show et al., 2011). Однако, несмотря на очевидные достоинства биоводородного топлива, его широкое внедрение сдерживается рядом нерешенных проблем: прежде всего, высокой стоимостью и небезопасностью транспортировки, хранения и применения данного вида топлива (Cheng et al., 2011).

\section{Жидкое биотопливо}

Одним из наиболее перспективных источников энергии признаны жидкие биотоплива. Повышенный интерес к этому виду биотоплив обусловлен возрастающими потребностями транспортного сектора экономики, которые в настоящее время на $95 \%$ удовлетворяются углеводородами нефти (Варфоломеев и др., 2009). В развитых и некоторых развивающихся странах жидкие биотоплива рассматривают как наиболее перспективную альтернативу традиционным углеводородным моторным топливам (Demirbas, 2009a). В 2012 г. жидкое биотопливо обеспечило около 3 \% энергетических затрат дорожного транспорта в мире. Во многих странах Европы, Америки и Азии введен государственный контроль, регламентирующий либо способствующий росту по- требления биотоплива для транспорта в ближайшие годы (REN21, 2013).

Наиболее распространенные виды жидкого биотоплива - топливные спирты и биодизель.

Спирты (метанол, этанол, пропанол, бутанол) используются как улучшающая добавка к бензину. В настоящее время наиболее широкое распространение получил этанол, который идет в основном в качестве 10-20\%-ной добавки к бензину. Иногда в качестве топлива применяют чистый этанол либо смесь с высоким содержанием этанола (85 \%), однако в этом случае необходима модификация двигателя (Ameri et al., 2008). Добавление этанола к бензину позволяет улучшить эксплуатационные характеристики топлива, поскольку процесс сгорания такой смеси гораздо эффективнее, чем чистого бензина.

В то же время применение биоэтанола имеет ряд существенных недостатков. У этанола относительно невысокая теплотворная способность, на 34 \% меньше по сравнению с таковой бензина, что увеличивает расход топлива. Высокая способность этанола к поглощению воды может приводить к расслоению смесевого топлива и накладывает ряд ограничений на его транспортировку и хранение (Balat et al., 2008). В связи с этими недостатками в последнее время возрос интерес к производству другого спирта - бутанола.

Бутанол, как и этанол, используется в качестве улучшающей добавки к бензину. Однако бутанол может добавляться к бензину в более высоких концентрациях, чем этанол, не требуя при этом модификации существующих двигателей. При сжигании бутанола энергии выделяется на $25 \%$ больше, чем при сжигании этанола. Топливный бутанол менее агрессивен и гигроскопичен, поэтому может транспортироваться по существующим топливным трубопроводам. Биобутанол более 
безопасен при использовании, поскольку испаряется значительно медленнее, чем бензин и этанол (Nigam, Singh, 2011). Таким образом, топливный бутанол - перспективная альтернатива топливному этанолу и бензину.

\section{Биодизельное топливо}

Другим распространенным видом жидкого биотоплива является биодизельное топливо (биодизель), представляющее собой смесь алкиловых эфиров жирных кислот (Knothe et al., 2005).

Впервые растительное масло, аналог биодизеля, было использовано в качестве топлива в двигателе внутреннего сгорания в 1900 г. на Международной выставке в Париже. На этом опытном образце Рудольф Дизель продемонстрировал работу двигателя на арахисовом масле (Pousa et al., 2007). Позднее он отметил: «Растительные масла в качестве топлива могут казаться сегодня малозначимыми, однако со временем они будут так же важны, как ископаемые топлива» (Беренблюм и др., 2010). Это высказывание выдающегося инженера и изобретателя оказалось пророческим. Действительно, из-за низких цен на ископаемые энергоносители интерес к биотопливу на начальном этапе развития автомобилестроения довольно быстро угас и возрождался только в периоды энергетических кризисов, во время и после Второй мировой войны. В современный период рост производства биотоплива был вызван энергетическим кризисом 70-х гг. XX в., когда мировые цены на нефть за несколько лет возросли в 14 раз (Булаткин, 2009; Pousa et al., 2007).

В результате во многих странах возобновили исследования, направленные на получение топлива, альтернативного ископаемому, на основе растительных масел. Однако было установлено, что непосредственное использование растительных масел, т.е. смесей триа- цилглицеринов, в двигателях внутреннего сгорания неэффективно и нежелательно ввиду их высокой вязкости (Karmakar et al., 2010; Knothe, 2010). Для решения этой проблемы было предложено использовать в качестве биодизеля не смеси жиров, а продукт их переработки - алкиловые эфиры жирных кислот (Knothe et al., 2005). В настоящее время биодизель является одним из наиболее широко используемых альтернативных источников энергии для транспорта; его промышленное производство в мире с 2007 по 2012 гг. ежегодно увеличивалось на $17 \%$ и сейчас составляет около 22 млн т (Tolmac et al., 2014). Однако его доля по отношению к традиционному нефтяному топливу, используемому для нужд транспорта, достигла лишь 1-1,5 \%. Основными странами-производителями выступают США, Аргентина, Германия, Бразилия и Франция, но производство увеличивается и в развивающихся странах (REN21, 2013).

Биодизель применяется в качестве 2-25\%-ной добавки к обычному дизельному топливу (смеси биодизеля с дизельным топливом обозначают буквой В с указанием на процентное содержание биодизеля в смеси) и изредка в качестве полного заменителя дизеля (Knothe et al., 2005). В 2013 г. 27 стран имели утвержденный национальный регламент по добавкам биодизеля в транспортное топливо и еще 49 стран ввели госрегулирование, способствующее применению биотоплива для нужд транспорта. Кроме того, в ряде стран были установлены целевые показатели: увеличение доли биодизеля в транспортном топливе и соответствующее увеличение производства биодизеля к 2020 г. в среднем в два раза (Kocar, Civas, 2013).

Основные характеристики биодизельного топлива (теплотворная способность, цетановое число, йодное число, вязкость и т.д.) регламентируются в большинстве стран при- 
нятыми национальными стандартами (Knothe et al., 2005):

ASTM D6751 - стандартная спецификация для 100\%-ного биодизеля (В100) в США;

EN 14213 - европейский стандарт, регламентирующий свойства биодизеля, использующегося в качестве печного топлива;

EN 14214 - европейский стандарт, регламентирующий свойства биодизеля, использующегося в качестве автомобильного топлива.

Также приняты предварительные стандарты для биодизельного топлива в Бразилии, Австралии, Южной Африке и др. Стандарт EN 14214 вступил в силу в 2003 г. и действует в 29 европейских странах, являющихся членами Европейского комитета по стандартизации (Knothe et al., 2005). В России, в настоящее время, не имеется принятых стандартов для биодизельного топлива.

\section{Источники сырья}

\section{Биодизельное топливо}

первого поколения

В качестве сырья для производства биодизеля первого поколения были предложены сельскохозяйственные культуры - пшеница, рапс, соя, подсолнечник, кукуруза, сахарная свекла, из которых получали масла для дальнейшей переработки. Затем спектр сырьевых растительных масел был расширен за счет несъедобных или малопригодных в пищу культур, таких как ятрофа, масличная пальма и др. (Sawangkeaw, Ngamprasertsith, 2013). В настоящее время страны, лидирующие в промышленном производстве биодизеля, используют в качестве сырья в основном рапс (Евросоюз), сою (США, Аргентина, Бразилия) и масличную пальму (Малайзия, Филиппины) (Kocar, Civas, 2013). При этом урожайность используемых культур значительно варьирует: от 408 л биодизеля на 1 га для сои до 4515 л/га для масличной пальмы.
Мировой рост потребностей в биодизельном топливе привел к закономерному увеличению площадей сельскохозяйственных угодий, занятых сырьевыми культурами, в 2-3 раза за последние три десятилетия (Tolmac et al., 2014). Согласно расчетам Международного энергетического агентства, доля пахотных земель, используемых под «биодизельные» культуры, может увеличиться с 14 млн га (1\% общей пахоты) в 2004 г. до 53 млн га $(3,8 \%)$ в 2030 г. И хотя сейчас масличные культуры, целенаправленно выращиваемые для переработки в биотопливо, составляют лишь 3-4 \% от всей биомассы сельскохозяйственных растений, увеличение объемов их выращивания послужило толчком к изучению ряда вопросов, определяющих дальнейшее развитие производства биодизеля первого поколения.

Наиболее важным из таких вопросов стало противостояние биоэнергетики, основанной на сельскохозяйственном сырье, и пищевого сектора экономики. Для выращивания масличных культур требуются качественные пахотные площади, потенциал которых во многих регионах мира весьма ограничен. В результате выращивания масличных растений для производства биотоплива сокращается количество посевных площадей, используемых для возделывания продовольственных культур, что приводит к росту цен на продукты питания (Walker, 2009). В качестве одного из способов преодоления этой проблемы предлагается использование в производстве малоценного растительного сырья. Так, например, в Германии планируется открытие предприятия, производящего биотопливо из всей биомассы рапса, что даст увеличение выработки биодизеля до 3300 л/га (Tolmac et al., 2014). Другим подходом служит освоение бросовых неплодородных земель для выращива- 
ния непищевых культур с высоким содержанием масел, что происходит в Индии, Китае, Таиланде и других азиатских странах (Sawangkeaw, Ngamprasertsith, 2013). Однако очевидно, что вовлечение всё новых земель в сельскохозяйственные циклы может иметь крайне негативные экологические последствия: сокращение площадей природных экосистем, снижение биоразнообразия, вымирание видов.

Еще одним недостатком сельскохозяйственного сырья является его высокая стоимость, составляющая до 80 \% от общей стоимости биодизеля первого поколения (Tracking Clean Energy Progress, 2013). Очевидно, что значительные затраты на получение сельскохозяйственного сырья вызваны необходимостью использования сельскохозяйственной техники, пестицидов, удобрений, проведения регулярных работ по восстановлению плодородия почв, селекционных и генно-инженерных работ для увеличения урожайности. Большие затраты на производство сырья определяют достаточно высокую стоимость продукта - биодизеля, составляющую 0,4-0,9 дол. США за литр (REN21, 2013), что в среднем в 2-3 раза дороже стоимости нефтяного дизеля (Sadeghinezhad et al., 2013). Стоимость биодизеля первого поколения значительно колеблется в зависимости от урожайности сырьевых культур.

Перечисленные экономические и экологические проблемы, связанные с производством биодизеля первого поколения, ограничивают развитие данного сектора энергетики (Tracking Clean Energy Progress, 2013). Поэтому производство биотоплива из сырья непищевого назначения, т.е. биодизеля второго и третьего поколений, приобретает все большую актуальность (Варфоломеев и др., 2009; Karmakar et al., 2010).
Биодизельное топливо

второго поколения

К биотопливу второго поколения относят топливо, произведенное из любых отходов (коммунально-бытовых, пищевой и деревообрабатывающей промышленности, сельского хозяйства). Очевидно, что производство такого биодизельного топлива позволит не только избежать конкуренции биоэнергетики с пищевым сектором экономики, но и решить, по крайней мере частично, проблемы утилизации отходов различных производств (Беренблюм и др., 2010; Феофилова и др., 2010; Oner, Altun, 2009; Siddiquee, Rohani, 2011). Прогнозируется также снижение стоимости такого биодизеля ввиду отсутствия затрат на производство исходного сырья (Tracking Clean Energy Progress, 2013).

Одним из перспективных видов сырья для производства биотоплива второго поколения признаны жиры, непригодные в пищу (отработанные пищевые жиры и масла, называемые в международной литературе «yellow grease»). По оценкам специалистов, на каждого жителя крупного города в год приходится около 4 кг таких отходов. Еще больше жиросодержащих отходов можно выделить из сточных вод больших городов («brown grease»), их масса составляет около 6 кг/год на каждого жителя (Беренблюм и др., 2010). Легко подсчитать, что для города с населением 1 млн человек количество «yellow grease» и «brown grease» составляет около 10 тыс. т в год, из которых можно получить примерно такое же количество биодизельного топлива. Кроме того, в результате деятельности человека накапливаются и большие количества иных органических отходов, загрязняющих окружающую среду. Получение биотоплива из техногенных органических отходов, несомненно, один из наиболее перспективных путей их переработки. 
Биодизельное топливо

третьего поколения

Биотопливо третьего поколения получают из биомассы микроводорослей или гетеротрофных микроорганизмов (Chisti, 2007; Demirbas, 2011). Выделение биотоплива третьего поколения обусловлено тем, что используемое сырье - целенаправленно выращиваемая биомасса микроорганизмов, не является пищевым источником, но и не может быть отнесено к отходам. Вместе с тем второе и третье поколения биотоплива зачастую рассматриваются совместно и считаются улучшенным топливом (advanced biofuel) в отличие от стандартного биодизеля первого поколения, получаемого из пищевого сырья. По некоторым оценкам, производство «advanced biofuel» составляло в 2012 г. лишь около 4 млн т, однако именно для этой категории биотоплива прогнозируется более чем 6-кратное увеличение производства к 2020 г. (Tracking Clean Energy Progress, 2013).

В настоящее время интенсивно исследуют возможности использования биомассы различных микроорганизмов (бактерий, грибов, дрожжей) в качестве сырья для производства биодизеля третьего поколения, однако микроводоросли продолжают оставаться наиболее перспективным сырьем (Lu et al., 2008; Сергеева и др., 2008; Karmakar et al., 2010). По сравнению с сельскохозяйственными культурами высших растений продуктивность микроводорослей выше в десятки, иногда сотни раз. Так, например, культура микроводослей объемом 1000 куб. м за год может произвести 3 т биомассы с высоким содержанием липидов, что даст биодизеля больше, чем годовой урожай с 0,5 га посадок масличной пальмы (Sawangkeaw, Ngamprasertsith, 2013). Для промышленного производства сейчас используется крайне ограниченное число видов микроводорослей, поэтому исследователи продолжают поиск штаммов, перспективных в отношении скорости роста и содержания липидов (Stansell et al., 2012; Abomohra et al., 2013; Xiao et al., 2013). Вместе с тем предложены методы генетического модифицирования, особенно актуальные для быстрорастущих штаммов микроводорослей, но с низким содержанием липидов. Так, получен модифицированный штамм хлореллы - водоросли, широко используемой для масштабного культивирования, с высоким содержанием липидов, до 40-60 \% от сухого веса (Liang, Jiang, 2013).

Для выращивания микроводорослей используют открытые и закрытые пруды, а также биореакторы. Затраты на создание и поддержание открытых прудов относительно невелики, однако при этом невысок выход биомассы, температура и освещенность, а следовательно, и продуктивность значительно варьируют, имеется риск заражения иными штаммами (Wijffels, Barbosa, 2010; Day et al., 2012). Также очевидно, что эффективное культивирование водорослей в открытых водоемах возможно лишь в регионах с теплым климатом и интенсивной инсоляцией. В свою очередь, технологии выращивания микроводорослей в биореакторах позволяют достичь существенно большего выхода биомассы, но отличаются большими затратами на создание и поддержание таких систем (Chisti, 2007; Demirbas, Demirbas, 2010; Wijffels, Barbosa, 2010). В биореакторах наряду с необходимостью рециркуляции и газообмена культивационной среды следует поддерживать оптимальную температуру (Феофилова и др., 2010). Использование для этой цели сбросного тепла электростанций способно удовлетворить до 77 \% тепловых потребностей биореакторов, что делает производство биодизеля из микроводорослей более экономически привлекательным (Беренблюм и др., 
2010). Однако теплообмен открытым способом может приводить к заражению культур посторонней микрофлорой, а альтернативная закрытая система теплообмена значительно увеличивает стоимость производства (Феофилова и др., 2010).

Существенным недостатком микроводорослей как сырья для биодизельного топлива является высокое содержание полиненасыщенных жирных кислот (ПНЖК) в липидах, что приводит к снижению окислительной стабильности и ухудшению некоторых других топливных характеристик биодизеля (Stansell et al., 2012, Xiao et al., 2013).

Несмотря на высокую продуктивность многих современных штаммов микроводорослей, стоимость масла из их биомассы остается очень высокой - до 5 дол. США/кг, что в несколько раз выше стоимости масел сельскохозяйственных культур (Wijffels, Barbosa, 2010; Sawangkeaw, Ngamprasertsith, 2013). Наиболее затратной технологической операцией признан сбор биомассы микроводорослей и ее подготовка к переработке в биодизель, заключающиеся в различных комбинациях центрифугирования, химической флоккуляции и фильтрования. Обработка биомассы микроводорослей к тому же должна идти весьма быстро, чтобы избежать ферментативного отщепления свободных жирных кислот от липидов. Производство биодизеля из биомассы микроводорослей считается очень перспективным с экологической и социальной точек зрения, что служит стимулом к поиску и развитию технологий, позволяющих снизить его стоимость. В результате дискуссии, развернувшейся на страницах журнала Science, исследователи пришли к выводу о том, что промышленное масштабирование выращивания микроводорослей существенно снизит стоимость получаемой биомассы (Wijffels, Barbosa, 2010). Другим путем к снижению стоимости является использование миксотрофных культур водорослей, обладающих более высокими скоростями роста (Wang et al., 2014), а также способных расти на различных отходах, например стоках очистных сооружений, и тем самым очищать воду от органических соединений (Li et al., 2011). Наконец, интересным и, возможно, самым эффективным может оказаться интегрированный подход, при котором выращиваемая биомасса микроводорослей используется как для получения биодизеля, так и иных целевых пищевых или непищевых продуктов (da Silva et al., 2014). Предлагаются и новые методы и катализаторы переработки биомассы микроводорослей в биодизель, позволяющие удешевить этот процесс (напримep, Tran et al., 2013).

\section{Получение \\ биодизельного топлива}

Получение биодизельного топлива основано на химической переработке липидов различных биоресурсов. Основные этапы стандартной технологиии производства биодизеля (в присутствии щелочного катализатора) приведены на рис. 1. Однако в настоящее время предлагаются и принципиально иные способы химической переработки, например основанные на ферментных системах, пиролизе, сложных катализаторах (Lam et al., 2010).

\section{Получение липидной фракциии биомассы}

Липидную фракцию семян и плодов сельскохозяйственных культур растений и биомассы животных получают, как правило, прессованием. Если в качестве сырья используются биоресурсы с более сложным химическим составом по сравнению с сельскохозяйственным сырьем, первоначальной стадией технологического процесса является экстрак- 


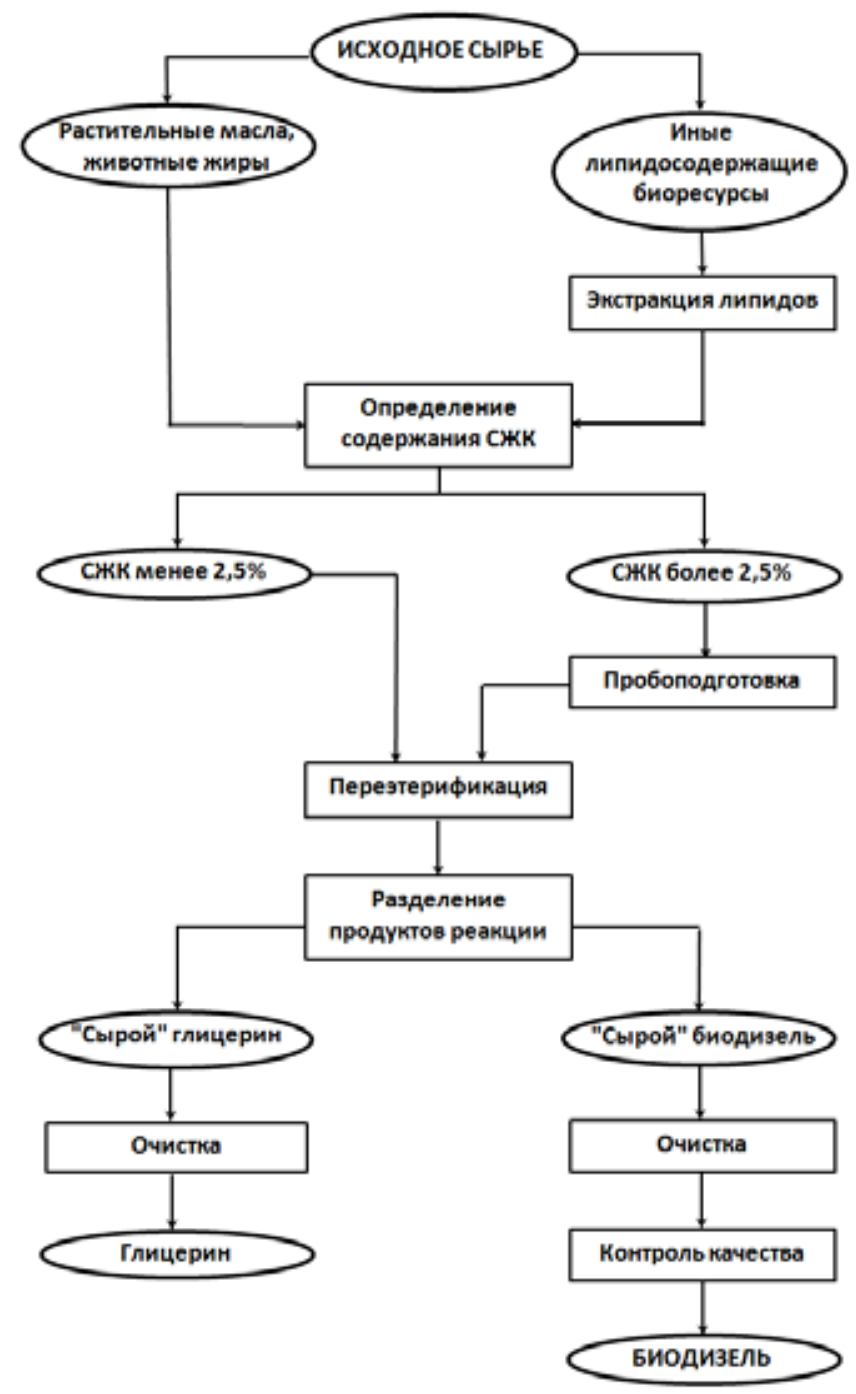

Рис. 1. Схема получения биодизельного топлива (Gerpen, 2005; Demirbas, 2009b; Leung et al., 2010)

ция липидов. Наиболее часто экстракцию выполняют с помощью отдельных органических растворителей (хлороформ, гексан, толуол) или их смесей (метод Фолча и др.). Нередко для повышения эффективности экстрагирования растворителями биомассу предварительно высушивают и гомогенизируют или проводят экстракцию при повышенных давлении и температуре, электрических импульcax (Xiao et al., 2013). Весьма эффективным и экологически безопасным методом служит суперкритическая флюидная экстракция, но этот метод мало распространен из-за его высокой стоимости. Сырье сложного состава, например биомассу водорослей, иногда обрабатывают и более дешевым прессованием, однако это позволяет выделить лишь около 70 \% липидной фракции (Demirbas, 2009b; Siddiquee, Rohani, 2011).

Также в литературе описаны способы получения биодизельного топлива из липидсодержащих биоресурсов без предварительного выделения липидной фракции. В этом случае реакцию переэтерификации проводят in situ. 
Как правило, данный способ применяют для исходного сырья с невысоким содержанием липидной фракции, например первичных и вторичных осадков очистных сооружений (Mondala et al., 2009).

\section{Реакиия переэтерификачии}

Для получения биодизеля выделенную из сырья липидную фракцию, содержащую преимущественно триацилглицерины (ТАГ), подвергают химической переработке. В основе этого процесса лежит реакция переэтерификации, т.е. взаимодействие ТАГ и иных сложных липидов со спиртами, протекающая при нагревании и в присутствии катализатора (Atadashi et al., 2011a). Переэтерифицирующим агентом является какой-либо спирт. Наиболее часто используют метанол ввиду его низкой стоимости по сравнению с другими спиртами (Leung et al., 2010). В этом случае реакцию переэтерификации называют метанолизом (Berrios, Skelton, 2008):

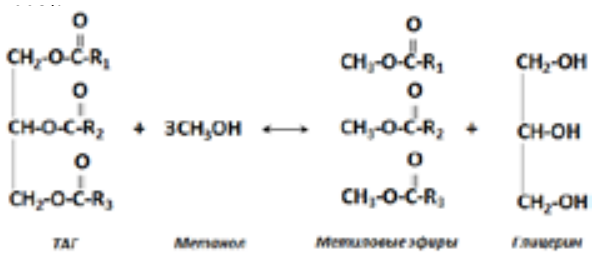

где $\mathrm{R}_{1}, \mathrm{R}_{2}, \mathrm{R}_{3}$ - углеводородные остатки высших (жирных) карбоновых кислот.

В результате переэтерификации образуются два ценных продукта - глицерин и смесь метиловых эфиров жирных кислот, которые необходимо разделить и очистить от примесей (рис. 1). После прохождения стадии очистки и при условии соответствия требованиям стандартов полученная смесь метиловых эфиров ЖК может использоваться в качестве биодизеля. Глицерин также нередко выделяют из реакционной смеси и после очищения используют в промыш- ленности, сельском хозяйстве, медицине (Berrios, Skelton, 2008).

Условия реакции, такие как температура, время, соотношение реагентов и тип используемого катализатора, зависят от химического состава исходного сырья и в каждом конкретном случае подбираются экспериментально так, чтобы выход целевого продукта был максимальным (Vicente et al., 2004). Важно отметить, что выход целевого продукта - биодизельного топлива - определяется также и качеством подготовки исходного сырья. Таким образом, выбор условий подготовки и переработки исходного сырья в биодизель может оказывать значительное влияние на стоимость и качество получаемого биотоплива.

\section{Подготовка сырья}

или липидной фракции к реакциии

Липидная фракция, выделенная из сырья, может содержать примеси, такие как свободные жирные кислоты (СЖК), воду и др. В связи с этим перед проведением реакции переэтерификации, как правило, проводят дополнительную обработку сырья.

Снижение доли СЖК необходимо в случае использования щелочных катализаторов, так как они реагируют с кислотами с образованием солей (мыла) и воды (реакция омыления):

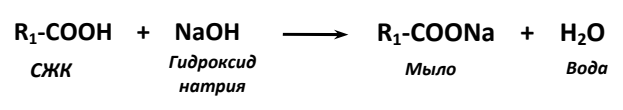

Протекание реакции омыления во время переэтерификации нежелательно: снижается выход биодизеля, затрудняется процесс разделения метиловых эфиров ЖК и глицерина. Кроме того, затрачивается большее количество катализатора, поскольку часть его вступит в реакцию омыления. Следовательно, 
если содержание СЖК в исходном сырье превышает 1-2,5 \%, то щелочные катализаторы не используют либо проводят предварительную подготовку сырья (Karmakar et al., 2010; Leung et al., 2010).

Для снижения процентного содержания СЖК в исходном сырье применяют методы паровой дистилляции, экстракции спиртом и этерификации в присутствии катализатора (Leung et al., 2010). Метод паровой дистилляции осуществляется при повышенных температурах и малоэффективен. Экстракция спиртом осложняется плохой растворимостью в нем СЖК. Таким образом, наиболее эффективным и простым является метод этерификации:

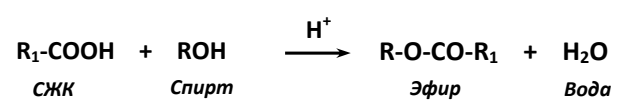

В качестве катализатора используют кислоту или йод. Преимущество йода как катализатора заключается в возможности его многократного использования, так как йод легко отделить от продуктов реакции. Однако при высоком исходном содержании СЖК в сырье образуется большое количество воды, которая ингибирует протекание реакции. В этом случае, чтобы достичь существенного снижения концентрации СЖК, необходимо проводить этерификацию исходного сырья несколько раз.

В качестве альтернативы многократной этерификации для сырья, содержащего большое количество СЖК, был предложен метод этерификации не метанолом, а трехатомным спиртом - глицерином при высокой температуре $\left(200{ }^{\circ} \mathrm{C}\right)$ в присутствии катализатора, хлорида цинка. В реакции образуются преимущественно моно- и диацилглицерины (МАГ, ДАГ), а вода испаряется. Но у этого метода есть недостатки: относительно низкая скорость реакции и необходимость поддержания высокой температуры.

Помимо СЖК протеканию реакции переэтерификации в присутствии щелочных катализаторов может мешать вода. Вода может гидролизовать ТАГ с образованием ДАГ, МАГ и СЖК, которые вступают во взаимодействие со щелочным катализатором:

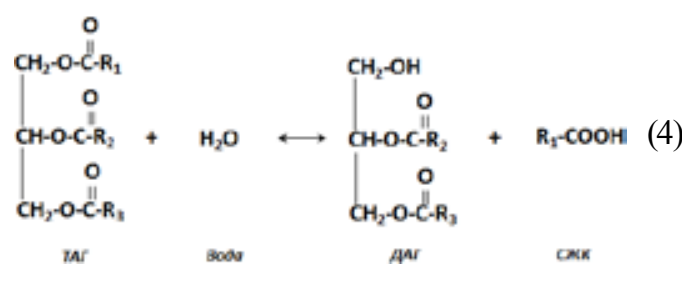

Поэтому для успешного проведения реакции переэтерификации необходимо провести осушение исходного сырья (Leung et al., 2010).

\section{Катализаторы реакциии}

переэтерификаиии

Реакция переэтерификации может проводиться в присутствии различных гомогенных и гетерогенных катализаторов: щелочных, кислотных, ферментативных (Helwani et al., 2009; Knothe, 2010).

Наиболее часто используют дешевые гомогенные щелочные катализаторы: метоксиды и гидроксиды щелочных металлов. В присутствии щелочных катализаторов достигается высокий выход целевого продукта за весьма короткое время. Реакцию проводят при невысокой температуре $\left(60-70{ }^{\circ} \mathrm{C}\right)$ и атмосферном давлении. Максимальный выход биодизеля (около 100 \%) достигается при использовании метоксида натрия, несколько ниже (около 99 \%) - при метоксиде калия, тогда как гидроксиды натрия и калия в качестве катализаторов обеспечивают заметно меньший выход продукта - 87 и $92 \%$ соответственно (Vicente et al., 2004). Более 
низкий выход целевого продукта обусловлен протеканием реакции омыления ТАГ (уравнение 2). При использовании всех типов гомогенных щелочных катализаторов содержание метиловых эфиров жирных кислот в полученном биодизеле составляет практически $100 \%$, что полностью удовлетворяет требованию к чистоте согласно стандарту EN 14214 (Knothe, 2005). Продолжительность реакции переэтерификации зависит от вида используемого щелочного катализатора, т.е. молекулярного веса и задействованных механизмов реакции. Минимальная продолжительность реакции составляет $\sim 30$ мин при использовании гидроксида натрия, несколько дольше - в присутствии метоксида натрия и гидроксида калия ( 45 мин). При применении в качестве катализатора метоксида калия скорость реакции переэтерификации будет значительно ниже из-за образующихся метоксид-ионов (Vicente et al., 2004). Существенным недостатком щелочных катализаторов является их высокая чувствительность к присутствию СЖК и воды в исходном сырье (см. выше).

Кислотные катализаторы (серная и соляная кислоты, сульфокислоты) применяют, как правило, лишь при высоком (более 1-2.5 \%) содержания СЖК в липидной фракции, поскольку эти вещества катализируют процесс как переэтерификации, так и этерификаци. Редкое применение кислотных катализаторов обусловлено их недостатками: реакция протекает значительно медленнее (примерно в 4000 раз по сравнению со щелочными катализаторами), при более высоких температурах и нередко при повышенном давлении. Использование кислотных катализаторов приводит к более высокому расходу метилового спирта. Так, молярное соотношение метанол : ТАГ составляет около 6:1 и 20:1 в присутствии щелочных и кислотных катализаторов соответственно (Karmakar et al., 2010). Также увеличивается расход самого катализатора (содержание кислотных катализаторов в реакционной смеси составляет 3-4 \%, а щелочных - не более 1,5 \%). Низкая каталитическая активность кислот обусловлена механизмом протекающей реакции (рис. 2).

Протонирование карбонильной группы считается ключевым этапом взаимодействия «катализатор - реагент», поскольку в результате именно этого процесса происходит увеличение электрофильности примыкающего атома углерода и молекула интермедиата становится чувствительной к нуклеофильной атаке (рис. 2). При использовании щелочных катализаторов атака карбонильного атома углерода сильным нуклеофилом (метоксидионом) происходит сразу. Именно это различие в механизме действия кислотных и щелочных катализаторов объясняет их различную каталитическую активность.

Кислотные гомогенные катализаторы, как и щелочные, чувствительны к присутствию воды в реакционной смеси. Вода является более сильным донором электронов по сравнению с алифатическими спиртами, что мешает образованию интермедиата по реакции II (рис. 2) (Christie, 1993). Так, показано, что даже незначительное присутствие воды (около $0,1 \%$ п) приводит к снижению выхода целевого продукта реакции переэтерификации, а при 5-6\%-ном содержании воды реакция прекращается.

Даже при низком содержании воды в реакционной смеси (менее $0,5 \%$ ) значительный выход метиловых эфиров ЖК (более 90 \%) в реакции с кислотным катализатором удается получить, лишь увеличив продолжительность реакции до 96 ч (Kusdiana, Saka, 2004). Очевидно, что столь значительное увеличение продолжительности технологического цикла с заметной потерей эффективности (по сравнению с применением щелочных катали- 

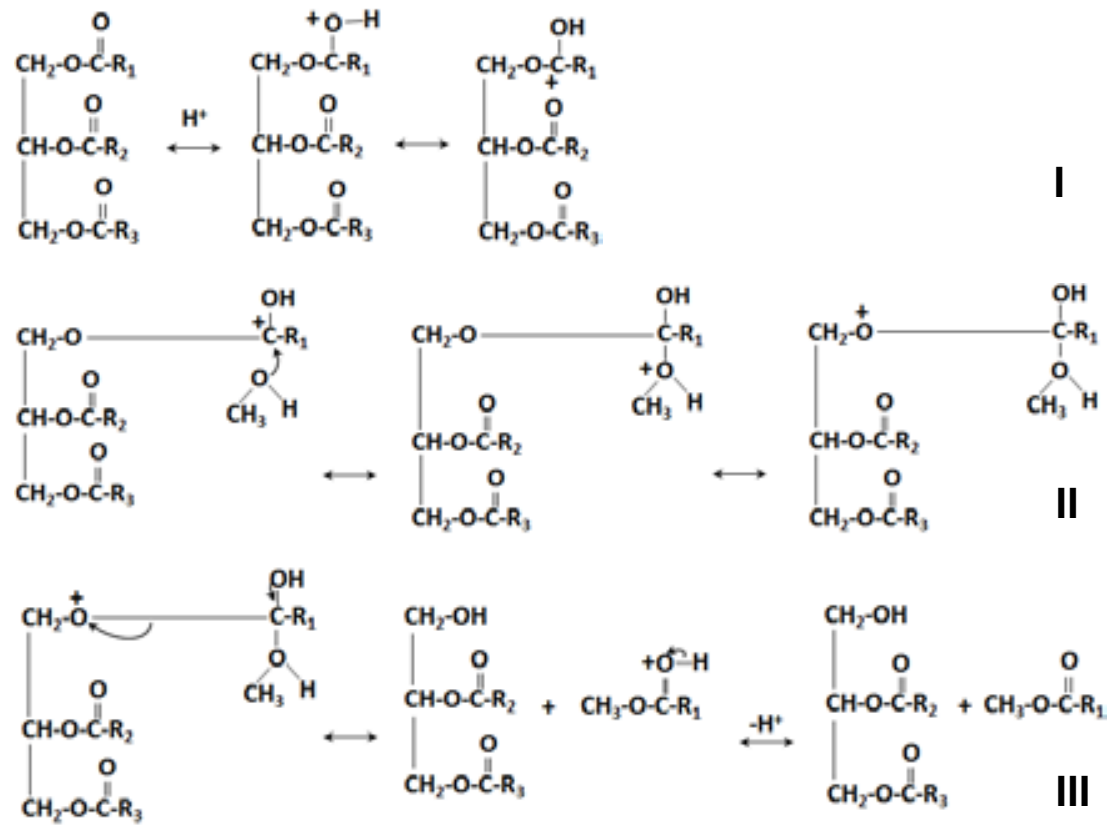

Рис. 2. Схема протекания реакции переэтерификации ТАГ в присутствии кислотного катализатора: I - протонирование карбонильной группы; II - нуклеофильное присоединение спирта с образованием тетраэдрического интермедиата; III - миграция протона и разрыв связи в интермедиате (Lam et al., 2010)

заторов) не является экономически привлекательным. Кроме того, кислоты в реакционной смеси ведут себя более агрессивно по сравнению со щелочами (Huang et al., 2010).

Ферментативные катализаторы, т.е. иммобилизованные липазы, самые безопасные гомогенные катализаторы. Кроме того, при их использовании удается избежать образования мыла, что существенно упрощает стадию очистки биодизельного топлива. Однако ферментативные катализаторы работают лишь при пониженных температурах (35-45 $\left.{ }^{\circ} \mathrm{C}\right)$, что значительно увеличивает продолжительность реакции (4-40 ч). Также существенным недостатком этих катализаторов служит их высокая стоимость по сравнению со щелочными и кислотными катализаторами (Lam et al., 2010).

В последние годы возрос интерес к гетерогенным катализаторам реакции переэтерификации, таким как силикаты титана, анионообменные смолы, оксид кальция и др. (Дундич и др, 2010; Jaruwat et al., 2010). Это связано, прежде всего, с меньшими требованиями к чистоте исходного сырья (гетерогенные катализаторы нечувствительны к присутствию воды и СЖК) и значительным упрощением стадии очистки метиловых эфиров ЖК (не происходит образования эмульсии, как в случае со щелочными гомогенными катализаторами). Кроме того, гетерогенные катализаторы более экологичны по сравнению с гомогенными. Однако высокая стоимость и необходимость применения высоких температур и давления ограничивают широкое распространение катализаторов такого типа.

Условия проведения реакичии переэтерификации

Соотношение исходных реагентов оказывает определяющее влияние на выход био- 
дизельного топлива. Согласно стехиометрии реакции (уравнение 1) для переэтерификации 1 моль ТАГ требуется 3 моля спирта. Однако, как правило, используют небольшой избыток метанола и соотношение метанол : липиды составляет от 6:1 до 9:1. При сложном составе липидной фракции сырья и (или) использовании кислотного катализатора переэтерификацию проводят при значительном избытке переэтерифицирующего агента, и вышеуказанное соотношение колеблется в пределах 20:1 - 60:1 (Miao, Wu, 2006; Helwani et al., 2009).

Температура и продолжительность реакции переэтерификации относятся к одним из главных факторов, влияющих на выход целевого продукта. Так, повышение температуры приводит к увеличению скорости переэтерификации ТАГ за счет снижения вязкости липидов. Однако показано, что превышение температуры выше оптимального уровня может привести к снижению выхода биодизеля, поскольку скорость побочной реакции (омыления ТАГ) при этом резко возрастает. Как правило, оптимальный температурный режим реакции определяется температурой кипения переэтерифицирующего агента (спирта) и составляет при использовании метанола 60-65 ${ }^{\circ} \mathrm{C}$ (Zhang et al., 2003; Knothe et al., 2005; Miao, $\mathrm{Wu}, 2006)$.

Продолжительность реакции переэтерификации зависит от природы и количества катализатора, состава сырья, соотношения исходных реагентов. Но превышение оптимального времени реакции может привести к снижению выхода биодизеля из-за протекания обратной реакции (Leung et al., 2010). Как правило, при использовании щелочных катализаторов продолжительность переэтерификации не более 60-90 мин, а в случае кислотных и ферментативных катализаторов варьирует от нескольких часов до нескольких суток (Vicente et al., 2004; Huang et al., 2010; Leung et al., 2010).

\section{Разделение продуктов реакциии}

Разделение биодизеля и глицерина основано на различиях в их полярности либо плотности. Различие в плотности биодизеля

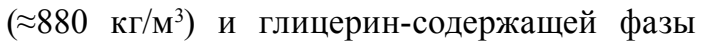
$\left(>1050\right.$ кг/ $\left.\mathbf{M}^{3}\right)$ позволяет использовать простые методы разделения, такие как гравитационное осаждение, центрифугирование, фильтрование (Atadashi et al., 2011a).

Гравитационное осаждение является дешевым методом разделения продуктов реакции переэтерификации, однако требует значительных временных затрат (1-8 ч). Центрифугирование дает возможность разделить продукты реакции значительно быстрее, но его применение ограничено из-за высокой стоимости.

В последние годы предложен метод отделения и очистки биодизеля фильтрованием через мембранные фильтры (обычно используют микропористые керамические мембраны). Этот метод позволяет получить биодизель высокой степени чистоты без значительных энергетических затрат (Atadashi et al., 2011b).

\section{Очистка биодизеля}

Получаемый после реакции переэтерификации биодизель, т.е. смесь метиловых эфиров жирных кислот (МЭЖК), должен соответствовать требованиям стандартов, регламентирующих его чистоту и уровни различных примесей (Knothe et al., 2005). В связи с этим очистка МЭЖК - обязательная стадия процесса получения биодизельного топлива. Неочищенный биодизель может содержать различные примеси, оказывающие отрицательное влияние на физико-химические и, как следствие, эксплуатационные свойства 
Таблица 1. Влияние различных примесей на свойства биодизельного топлива и работу двигателя внутреннего сгорания (Berrios et al., 2008)

\begin{tabular}{|l|l|}
\hline \multicolumn{1}{|c|}{ Примесь } & \multicolumn{1}{c|}{ Влияние на свойства биодизеля } \\
\hline СЖК & $\begin{array}{l}\text { Снижение окислительной стабильности топлива; } \\
\text { коррозия элементов двигателя }\end{array}$ \\
\hline Вода & $\begin{array}{l}\text { Образование СЖК в результате протекания реакции гидролиза; } \\
\text { рост бактерий с последующим засорением фильтров; } \\
\text { коррозия элементов двигателя }\end{array}$ \\
\hline Метанол & $\begin{array}{l}\text { Снижение температуры воспламенения (ограничения при транспортировке, } \\
\text { хранении и использовании топлива); } \\
\text { коррозия алюминий- и цинксодержащих деталей двигателя }\end{array}$ \\
\hline Глицериды & $\begin{array}{l}\text { Увеличение вязкости топлива; } \\
\text { осаждение в топливных насосах, засорение фильтров }\end{array}$ \\
\hline $\begin{array}{l}\text { Соли металлов } \\
\text { (мыла, катализатор) }\end{array}$ & $\begin{array}{l}\text { Осаждение в топливных насосах, засорение фильтров; } \\
\text { увеличение износа двигателя }\end{array}$ \\
\hline Глицерин & $\begin{array}{l}\text { Увеличение вязкости топлива; } \\
\text { осаждение в топливных насосах, засорение фильтров; } \\
\text { увеличение эмиссии альдегидов и акролеина }\end{array}$ \\
\hline
\end{tabular}

биодизеля (табл. 1). В настоящее время метиловые эфиры ЖК очищают от примесей двумя способами: влажной очисткой (промывание водой с последующей сушкой биодизеля или очистка органическими растворителями) и сухой очисткой (использование адсорбентов и мембран) (Berrios, Skelton, 2008).

При влажной очистке к неочищенному биодизелю добавляют определенное количество смеси воды и кислоты. Глицерин и метанол очень хорошо растворяются в воде, поэтому этот метод весьма эффективен и позволяет получить биодизель с требуемой степенью чистоты. Добавление некоторого количества кислоты к воде (наиболее часто используют фосфорную, соляную или серную кислоты) дает возможность нейтрализовать остатки щелочного катализатора и уменьшить концентрацию натриевых/калиевых солей жирных кислот, что, в свою очередь, уменьшает образование эмульсии (Leung et al., 2010). Использование горячей воды повышает эффективность очистки. Процесс заканчивают, когда очередная до- бавленная порция воды остается прозрачной, что свидетельствует о полном удалении примесей. После очистки МЭЖК осушают, как правило, под вакуумом, что требует значительных энергетических и временных затрат (Atadashi et al., 2011b).

Одним из недостатков этого метода очистки биодизеля является образование больших объемов загрязненной воды, до $28 \%$ от исходного объема липидов. Так, в Таиланде при ежедневном производстве около 350000 л биодизеля количество воды, загрязняемой при его очистке, составляет около 70000 л/день. Присутствие в воде загрязняющих веществ ингибирует рост и размножение микроорганизмов, что, в свою очередь, затрудняет ее очищение путем естественной деградации (Jaruwat et al., 2010). Другим недостатком этого метода признано образование эмульсии воды с мылом, что приводит к значительным потерям метиловых эфиров ЖК, до 18 \% (Atadashi et al., 2011b). Несмотря на перечисленные недостатки, данный метод очистки биодизеля от примесей сейчас наиболее распространен (Berrios, Skelton, 2008). 
Для очистки МЭЖК от примесей также используют органические растворители, такие как петролейный эфир, гексан. Растворитель добавляют к реакционной смеси в соотношении 1:1 и экстрагируют МЭЖК при комнатной температуре. Однако далее также требуется использование воды для удаления мыла и катализатора. Органический слой промывают, как правило, горячей водой (около $50{ }^{\circ} \mathrm{C}$ ) до достижения нейтрального рН. Далее органическую смесь пропускают через осушитель (безводный сульфат натрия или магния) и удаляют растворитель на роторном вакуумном испарителе (Wang et al., 2007; Atadashi et al., 2011b). Очевидно, что данный метод очистки биодизеля имеет несколько серьезных недостатков: использование значительных объемов токсичных органических растворителей и оборудования для их удаления, загрязнение воды, что в итоге ведет к удорожанию готового продукта. Но этот способ хорошо подходит для сырья с низким содержанием липидов, например различных отходов.
Для очистки биодизеля применяют также технологии с использованием различных сухих адсорбентов (рис. 3). В качестве адсорбентов наиболее широко используются силикаты (магнезол, трисил), ионообменные смолы, активированный уголь, глина и др. Эти адсорбенты способны связывать кислоты и щелочи и имеют высокое сродство к полярным органическим веществам, таким как метанол, глицерин, мыла. Адсорбенты позволяют также устранить нежелательное окрашивание биодизеля, получаемого из некоторых биоресурсов. Очистка адсорбентами дает возможность получить биотопливо высокого качества. Данный способ очистки МЭЖК помогает избежать образования эмульсии и больших объемов загрязненной воды, не требует осушения биодизеля и значительных временных затрат, что снижает расходы.

Несмотря на вышеперечисленные достоинства, очистка биодизельного топлива от примесей с помощью адсорбентов не столь распространена, как очистка с помощью воды. Основным лимитирующим фактором явля-

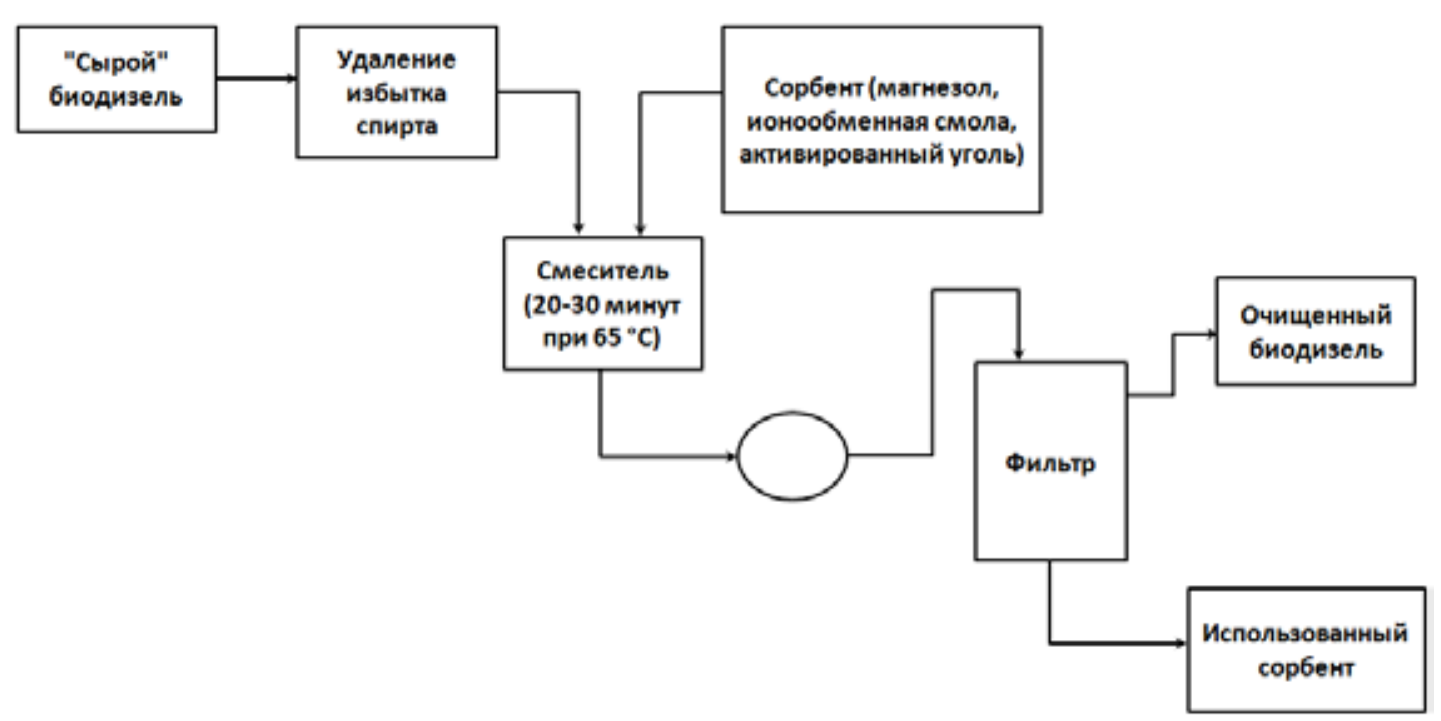

Рис. 3. Схема очистки биодизельного топлива с использованием адсорбентов (Atadashi et al., 2011a) 
ется малоизученность процесса. Кроме того, адсорбенты не всегда способны эффективно снизить содержание определенных примесей в топливе. Так, после очистки с помощью ионообменных смол содержание остаточного метанола в биодизеле превышало уровень, регламентированный стандартами (Atadashi et al., 2011b).

Для очистки биодизеля применяют также мембраны, позволяющие пропускать лишь определенные компоненты смеси. Мембраны могут быть гомогенными и гетерогенными, твердыми или жидкими, симметричной и асимметричной структуры, положительно и отрицательно заряженными или нейтральными.

Мембранная очистка МЭЖК позволяет получить биодизельное топливо высокой степени чистоты, при этом нет необходимости использовать воду, органические растворители, осушители, вакуумное испарение и т.п. Это существенно снижает затраты на процесс отделения и очистки биодизеля. Недостаток данной технологии - неустойчивость ряда мембран к органическим веществам, под действием которых они достаточно быстро разбухают и теряют свои свойства (Atadashi et al., 2011b). Очистка биодизеля с помощью мембран - относительно новый метод. В настоящее время интенсивно исследуется влияние типа используемых мембран, давления, температуры, скорости потока и взаимодействий между компонентами, проходящими через мембраны, на качество и скорость чистки биодизеля (Atadashi et al., 2011b), что поможет определить потенциал этой инновационной технологии очистки.

Таким образом, анализ технологических этапов переработки энергонасыщенной биомассы позволяет заключить, что каждый из этапов оказывает существенное влияние на качество и стоимость конечного продукта биодизельного топлива.

\section{Перспективы \\ и проблемы производства \\ биодизельного топлива}

По сравнению с традиционным дизельным топливом биодизель обладает рядом преимуществ. Прежде всего, биодизель, как и любой другой вид биотоплива, является возобновляемым источником энергии. Цикл, включающий производство (выращивание биомассы) и использование биодизеля (сжигание в двигателях), в итоге не ведет к техногенной эмиссии и накоплению углекислого газа в атмосфере в отличие от цикла добычи ископаемого топлива и сжигания нефтепродуктов. Во-вторых, биодизельное топливо относят к «экологически чистым» источникам энергии, поскольку негативные последствия его применения для окружающей среды существенно меньше по сравнению с нефтепродуктами (Tracking Clean Energy Progress, 2013). Так, содержание ароматических углеводородов и других веществ, обладающих канцерогенными, мутагенными, тератогенными свойствами для живых организмов, в биодизеле ниже по сравнению с нефтепродуктами; при попадании в почву или воду биодизель, как и нефть, полностью разлагается микроорганизмами (Knothe et al., 2005; Demirbas, 2009a). Биодизель практически не содержит серу, что приводит к существенному уменьшению выбросов $\mathrm{SO}_{2}$ в атмосферу по сравнению с традиционным дизельным топливом. Вследствие большего процентного содержания кислорода процесс сгорания биодизеля гораздо эффективнее по сравнению с дизельным топливом (Helwani et al., 2009). По данным большинства исследований, в выхлопных газах двигателя, образующихся при сгорании биодизеля, значительно снижается (в среднем 
на 50 \%) содержание углеводородов, твердых частиц сажи, моноксида углерода, а также ароматических соединений по сравнению с традиционным дизелем (Sadeghinezhad et al., 2013).

Биодизель характеризуется отличными смазочными свойствами, поэтому даже незначительная его добавка (1-2 \%) к традиционному дизелю заметно улучшает смазочные характеристики топлива. Биодизель имеет более высокую температуру воспламенения (не менее $120^{\circ} \mathrm{C}$ ) по сравнению с дизелем, что делает его использование и хранение более безопасным (Knothe, 2005; Demirbas, 2009a; Huang et al., 2010).

Несмотря на положительные аспекты применения биодизеля, предстоит преодолеть ряд вопросов и вызовов, связанных с развитием эффективного производства биодизельного топлива.

В настоящее время ряд эксплуатационных характеристик биодизельного топлива требует улучшения. Так, по сравнению с дизелем биодизель обладает более высокой вязкостью, низкой окислительной стабильностью, относительно высокой температурой кристаллизации и при его сгорании выделяется в среднем на $12 \%$ меньше энергии.

Повышенная вязкость топлива негативно влияет на работу топливных насосов и систему фильтрации, вследствие чего нарушается подача топлива в камеру сгорания, снижается эффективность сгорания, увеличивается расход топлива, может происходить полимеризация вещества с образованием отложений в двигателе (Xue et al., 2011).

Низкая окислительная стабильность одна из главных проблем биодизельного топлива. Вследствие окисления топлива ухудшается ряд его эксплуатационных характеристик (увеличивается вязкость, перекисное и кислотное число). Из-за низкой устойчивости к окислению биодизель имеет ограниченные сроки хранения (3-6 месяцев). В ряде случаев окислительная стабильность биодизельного топлива не удовлетворяет требованиям стандартов, значит, необходима добавка к топливу антиоксидантов, что увеличивает стоимость биодизеля и снижает его чистоту (Ryu, 2010).

Существенным недостатком биодизельного топлива является невысокая теплотворная способность (на 5-20 \% меньше, чем у дизеля), что увеличивает расход топлива (Oner, Altun, 2009; Xue et al., 2011).

Относительно высокая температура кристаллизации биодизеля накладывает ограничения на температурный диапазон эксплуатации и хранения. Например, биодизель, полученный из арахисового масла, начинает кристаллизоваться уже при температуре $10^{\circ} \mathrm{C}$, следовательно, использование такого топлива при более низких температурах приведет к отрицательным последствиям для топливной системы - может происходить отложение восков и забивание фильтров и топливных трубопроводов (Ramos et al., 2009).

Наряду с необходимостью улучшения эксплуатационных свойств основным ограничением широкого распространения биодизеля является его высокая стоимость, превышающая стоимость нефтедизеля примерно в два раза (Huang, 2010; Demirbas, 2008). Очевидно, что снижение стоимости биодизеля выступает одной из ключевых задач биоэнергетики.

В целом, можно выделить два основных подхода к решению данных проблем производства и применения биодизеля.

Первый подход подразумевает использование современных видов биодизельного топлива и минимизацию недостатков их эксплутационных характеристик за счет применения смесевых топлив с низким содержанием биодизеля (B5-B20) (Knothe et al., 2005; 
Sadeghinezhad et al., 2013). В этом случае недостатки топливных характеристик биодизеля не будут оказывать существенного влияния на топливную систему. С другой стороны, для использования биодизеля и смесевых топлив предлагается провести модификацию двигателя (подогрев топливного бака, изготовление топливных шлангов, прокладок из устойчивых к биодизелю материалов и др.).

Второй подход нацелен на получение биодизельного топлива с лучшими эксплутационными характеристиками и меньшей себестоимостью (Day et al., 2012; Lam et al., 2012; Yan et al., 2014). Несомненно, технология получения (подготовка сырья, условия реакции, очистка биодизеля от примесей) существенно влияет на качество биодизельного топлива. Однако известно, что именно жирнокислотный состав сырья, используемого для производства биодизельного топлива, оказывает определяющее влияние на его эксплуатационные характеристики. Как показано выше, стоимость биодизельного топлива также в значительной степени определяется стоимостью исходного сырья. В этой связи поиск дешевых сырьевых источников, характеризующихся оптимальным химическим составом, и разработка простых и экономичных технологий переработки крайне актуальные задачи биоэнергетики.

\section{Влияние химического состава сырья}

на эксплуатационные характеристики

\section{биодизельного топлива}

Состав смеси эфиров жирных кислот биодизельного топлива определяется жирнокислотным составом липидов исходного сырья. В свою очередь, структурные характеристики жирных кислот определяют эксплуатационные характеристики биодизеля. Среди важнейших эксплуатационных характеристик следует отметить такие, как цетановое число (аналог октанового числа), окислительная способность, теплотворная способность, температурные свойства. Значения данных характеристик регламентируются стандартами по биодизельному топливу.

Цетановое число (ЦЧ) характеризует воспламеняемость дизельных топлив, т.е. величину задержки воспламенения смеси. Чем выше цетановое число, тем меньше задержка воспламенения и тем равномернее горит топливная смесь. В качестве эталонов для определения ЦЧ используют смеси цетана (н-гексадекана, $\mathrm{C}_{16} \mathrm{H}_{34}$ ) с $\alpha$-метилнафталином. Цетановое число $H$-гексадекана принято равным 100 , а показатель $\alpha$-метилнафталина -0 . Если испытываемое дизельное топливо характеризуется такой же воспламеняемостью в стандартных условиях, что и модельная смесь этих двух углеводородов, то его цетановое число считается равным процентной доле цетана в модельной смеси. ЦЧ традиционного дизельного топлива зависит от химического состава смеси углеводородов и, согласно некоторым стандартам (например, ASTM D975), должно быть не менее 40. ЦЧ биодизеля определяется жирнокислотным составом исходного сырья и, согласно требованиям европейского и американского стандартов, должно быть более 51. Известно, что ЦЧ эфиров жирных кислот зависят от длины цепи, степени ненасыщенности и разветвленности (Knothe et al., 2003). Высокие значения ЦЧ характерны для эфиров насыщенных и длинноцепочечных ЖК, в то время как увеличение степени ненасыщенности и разветвленности углеводородной цепи приводит к снижению ЦЧ. Так, биодизельное топливо, полученное из соевого и подсолнечного масла, характеризуется низкими значениями ЦЧ (49 и 50 соответственно), поскольку отличается высокими уровнями олеиновой и линолевой ЖК. Содержание этих кислот в пальмовом масле 
значительно ниже, что позволяет получать биодизельное топливо с более высоким ЦЧ, до 61 (Ramos et al., 2009). В свою очередь, при производстве биодизеля из биомассы микроводорослей ЦЧ может очень варьировать в зависимости от вида водоросли - от 39 до 54, в некоторых случаях выше 70 (Stansell et al., 2012; Xiao et al., 2013).

Теплотворная способность (теплота сгорания) биодизельного топлива, т.е. количество энергии, выделяемой при его сгорании, также зависит от состава исходного сырья. Согласно стандарту EN 14214, теплота сгорания биодизеля должна быть не менее 35 МДж/кг, что несколько меньше, чем средняя величина для нефтедизеля - 43,8 МДж/кг (Knothe et al., 2005). Максимальные величины теплоты сгорания имеют топлива с высоким содержанием насыщенных и длинноцепочечных эфиров ЖК. Биодизель, получаемый из рапсового масла, отличается одним из самых высоких значений среди продуктов из сельскохозяйственных культур - 37,2 МДж/кг (Сергеева и др., 2008; Ramos et al., 2009). Это связано с высоким содержанием в рапсе длинноцепочечных и моноеновых кислот, тогда как масла прочих культур содержат много ПНЖК. Теплота сгорания биодизеля, получаемого из микроводорослей, по некоторым данным, колеблется в пределах 37-41 МДж/кг (Huang et al., 2010; Xiao et al., 2013).

Очевидно, что присутствие длинноцепочечных насыщенных ЖК повышает энергонасыщенность сырья, увеличивает цетановое число и теплоту сгорания биодизеля. Однако следует иметь в виду, что повышенное процентное содержание этих ЖК также приводит к увеличению вязкости получаемого биотоплива (Allen et al., 1999). Поэтому считается, что наиболее перспективно для получения биодизеля с оптимальными топливными характеристиками сырье с повышенным содер- жанием мононенасыщенных жирных кислот (МНЖК) (Stansell et al., 2012).

Жирнокислотный состав также значительно влияет на окислительную стабильность (устойчивость к окислению) биодизеля. Такие факторы, как контакт с воздухом, источники тепла, света, присутствие металлов и пероксидов, заметно способствуют окислению эфиров ЖК. Показано, что окислительная стабильность биодизельного топлива коррелирует с содержанием ненасыщенных ЖК, поскольку наличие двойных связей в молекулах ЖК является основной причиной автоокисления (Knothe, 2007; Lapuerta et al., 2009; Karmakar et al., 2010). Большинство видов биодизеля, получаемого из растительного и микробного сырья, содержат большую долю эфиров олеиновой, линолевой и линоленовой кислот, что снижает окислительную стабильность топлива. В связи с этим европейский стандарт EN 14214 предписывает содержание в биодизеле линоленовой кислоты не более $12 \%$, а содержание ЖК с числом двойных связей $\geq 4$ не должно превышать $1 \%$ (Knothe et al., 2005).

Количественной мерой ненасыщенности биодизельного топлива является йодное число (ЙЧ), рассчитываемое как масса йода (г), присоединяющегося к 100 г топлива. Чем выше йодное число, тем больше ненасыщенных кислот содержится в биодизеле и тем ниже его окислительная стабильность. Согласно требованиям стандарта EN 14214, йодное число биодизеля не должно превышать 120. Как правило, жирнокислотный состав сырья, использующегося для производства биодизеля, удовлетворяет этому требованию, однако ряд биоресурсов (масло виноградных косточек, соевое, подсолнечное) из-за высокого содержания ПНЖК имеют более высокие значения ЙЧ (128-138), что снижает окислительную стабильность топлива (Ramos et al., 2009). 
Температурный диапазон эксплуатации и хранения биодизельного топлива также определяется жирнокислотным составом. Чем выше содержание ПНЖК, тем ниже температура замерзания топлива, что объясняется более низкими температурами плавления ПНЖК по сравнению с НЖК и МНЖК (Demirbas, 2009b). Низкотемпературные свойства топлива характеризуются значением CFPP (cold filter plugging point), т.е. самой низкой температуры, при которой определенный объем топлива проходит через стандартизованную систему фильтрации за заданное время (Knothe, 2010). Так, биодизель, полученный из пальмового масла, содержит большое количество ( $\approx 45 \%)$ метиловых эфиров пальмитиновой и стеариновой кислот, которые, как известно, уже при достаточно высоких температурах $\left(\mathrm{CFPP}=10^{\circ} \mathrm{C}\right)$ начинают затвердевать, забивая топливные фильтры (Ramos et al., 2009). Но наиболее высокое значение CFPP $\left(17{ }^{\circ} \mathrm{C}\right)$, т.е. наихудшие низкотемпературные свойства, присуще биодизелю из арахисового масла, что объясняется значительным содержанием ( $\approx 5 \%$ длинноцепочечных насыщенных ЖК - C22:0, С24:0.

Таким образом, жирнокислотный состав исходного сырья в итоге определяет большинство ключевых эксплуатационных характеристик биодизельного топлива. Однако химический состав является важным, но не единственным фактором, влияющим на выбор сырья для производства биодизеля. Не менее важное значение имеет стоимость исходного сырья, определяющая экономическую привлекательность конечного продукта - биодизеля.

\section{Стоимость биодизельного топлива}

В настоящее время стоимость биодизельного топлива продолжает оставаться достаточно высокой, что ставит под сомнение экономическую эффективность производства полезной энергии из биомассы. Снижение стоимости биотоплива признано одной из главных задач биоэнергетики (Tracking Clean Energy Progress, 2013).

Стоимость биодизельного топлива складывается из стоимости исходного сырья (производство биомассы, транспортировка и хранение) и затрат на технологический процесс получения топлива. Для биодизеля первого поколения основные затраты приходятся на производство исходного сельскохозяйственного сырья (Wassell, Dittmer, 2006). По различным оценкам стоимость такого сырья составляет 50-80 \% от итоговой стоимости биодизеля (Chisti, 2007; Huang et al., 2010). Например, в 2002 г. стоимость соевого масла в США составляла в среднем 0,36 US\$/л, что обусловило высокую стоимость полученного биодизеля, до 0,5 US\$ /л в сравнении со стоимостью дизельного топлива 0,35 US\$/л (Zhang et al., 2003). Одним из самых дешевых растительных масел является пальмовое, однако стоимость биодизельного топлива, полученного из этого сырья, превосходит стоимость нефтяного дизеля на $35 \%$ (Chisti, 2007). Сырьем для большей части современного мирового производства биодизеля служат масла сельскохозяйственных культур, что делает такое производство нерентабельным по сравнению с получением дизеля из нефти. Поэтому для обеспечения конкурентоспособности биодизеля на рынке энергоносителей для транспорта и снижения загрязнения атмосферы городов автотранспортными выхлопами в большинстве стран применяется государственное субсидирование и регулирование.

С другой стороны, продолжается поиск дешевых энергонасыщенных источников сырья. Предполагается, что биодизель второго и третьего поколений будет в конце 
концов рентабельным продуктом. Однако сейчас сырье для биодизеля третьего поколения (биомасса водорослей и микроорганизмов) весьма дорогостоящий продукт в связи с большими затратами на выращивание и сбор биомассы (Demirbas, Demirbas, 2010; Wijffels, Barbosa, 2010). Предложены технологические методы, позволяющие удешевить биодизель из биомассы микроорганизмов (см. выше), но снижение финансовых вложений в биоэнергетические исследования, происходящее в последние годы, может замедлить достижение поставленных задач (REN21, 2013).

Очевидно, что использование в качестве сырья отработанных жиров и масел сельскохозяйственных и других липидсодержащих отходов позволит существенно снизить стоимость биодизеля (Беренблюм и др., 2010). Однако объемы отходов, богатых липидами, например отработанных жиров заведений общественного питания, невелики и, очевидно, могут быть использованы лишь как дополнительный источник для производства биодизеля (Sawangkeaw, Ngamprasertsith, 2013). В этой связи интерес могут представлять липидсодержащие отходы, накапливающиеся в значительных количествах, например первичные и вторичные осадки муниципальных канализационных очистных сооружений сточных вод (Mondala et al., 2009). Однако предварительная подготовка данного вида сырья требует значительных энергетических затрат. Так, стоимость подготовки осадков очистных сооружений, согласно оценкам авторов статьи, составляет $53 \%$ от конечной стоимости биодизеля, что, однако, заметно ниже затрат на производство растительных масел. Выполненный экономический анализ показал, что стоимость биодизеля, полученного из муниципальных отходов, несмотря на сложный и дорогостоящий процесс подготовки, соста- вила 3,23 US\$ /галлон, что оказалось значительно ниже стоимости дизеля, составлявшей 4,80 US\$/галлон (Mondala et al., 2009). Кроме того, авторы работы не учли экономическую стоимость отчуждения земель, занимаемых под длительное хранение и ремедиацию первичных и вторичных осадков, формирующихся при работе канализационных сооружений. Очевидно, что высвобождение этих площадей будет дополнительным фактором, снижающим стоимость биодизеля, получаемого при переработке отходов канализационных сооружений.

\section{Заключение}

Исследования в области биоэнергетики, направленные на получение жидкого топлива - биодизеля, являются актуальным, бурно развивающимся направлением. Это связано, прежде всего, с экологической безопасностью данного вида топлива и его значением как потенциальной экономической альтернативы транспортному топливу, производимому из нефти. Продолжаются поиск и оценка возобновляемых биоресурсов, пригодных к переработке, предлагаются новые способы переработки биомассы и отходов, что в итоге нацелено на создание экономически рентабельных технологий и промышленных процессов получения биодизельного топлива. Очевидно, что Российская Федерация должна обладать собственными высокоэффективными технологиями по переработке возобновляемых биоресурсов в биотопливо. Исследования должны быть ориентированы, прежде всего, на возобновляемые сырьевые источники, актуальные для России.

На наш взгляд, в климатических условиях Сибири одними из наиболее перспективных источников сырья для производства биодизельного топлива могут оказаться осадки эвтрофных водоемов и канализационных 
очистных сооружений. Донные осадки накапливаются в озерах и водохранилищах в результате осаждения отмерших или зимующих клеток, преимущественно водорослей и бактерий. Особенно велико их накопление в эвтрофных водоемах. Аноксигенные черные илы служат источником регенерации и поступления в воду соединений фосфора, стимулирующего «цветение» воды цианобактериями и микроводорослями. Кроме того, после «цветения» значительная часть клеток и колоний формирует покоящиеся формы, пребывающие на дне водоема до следующего вегетационного периода. Поэтому удаление донных отложений считается эффективным методом борьбы с «цветением» воды (Annadotter et al., 1999) и зачастую входит в состав природоохранных мероприятий, направленных на восстановление качества воды «цветущих» озер и водохранилищ. Представляется экономически перспективным использовать илы, получаемые при этом как побочный продукт, в качестве возобновляемого сырья для производства биотоплива (Kuchkina et al., 2011; Sushchik et al., 2013).

Подобно естественным процессам накопления донных осадков в водоемах на дне иловых карт различных муниципальных и промышленных очистных сооружений происходит антропогенное накопление (складирование) первичных и вторичных осадков. Сброс осадков очистных сооружений крупных городов на иловые карты в настоящее время служит основным способом их утилизации за счет механического обезвоживания и длительной биодеградации. Данный способ утилизации осадков сточных вод приводит к длительному и, как правило, безвозвратному отчуждению значительных земельных ресурсов. Вполне вероятно, что промышленная переработка осадков очистных сооружений в биодизель позволит решить как важную экологическую проблему, связанную с их утилизацией, так и проблему высокой стоимости биодизельного топлива. Очевидно, что работы в этом направлении весьма актуальны и требуют интенсивного продолжения.

\section{Список литературы}

1. Беренблюм А.С., Данюшевский В.Я., Кацман Е.А., Подоплелова Т.А., Флид В.Р. (2010) Получение моторных топлив из непищевых растительных масел и жиров. Нефтехимия. 50(4): 317-323.

2. Булаткин Г.А. (2009) Оценка эффективности производства нетрадиционных и возобновляемых источников энергии. Вестник РАН. 79(7): 608-616.

3. Варфоломеев С.Д., Моисеев И.И., Мясоедов Б.Ф. (2009) Энергоносители из возобновляемого сырья. Вестник РАН. 79 (7): 595-604.

4. Джирард Д.Е. (2008) Основы химии окружающей среды. М.: ФизМатЛит, 640 с.

5. Дундич В.О., Хромова С.А., Ермаков Д.Ю., Лебедев М.Ю., Новопашина В.М., Систер В.Г., Ямчук А.И., Яковлев В.А. (2010) Исследование никелевых катализаторов реакции гидродеоксигенации биодизеля. Кинетика и Катализ. 51 (5) 728-734.

6. Моисеев И.И. (2011) Бактериальный синтез в индустрии топлив и нефтехимии. Вестник PAH. 81(5): 405-413.

7. Сергеева Я.Э., Галанина Л.А., Андрианова Д.А., Феофилова Е.П. (2008) Липиды мицелиальных грибов как основа для получения биодизельного топлива. Прикладная биохимия и микробиология. 44: 576-581. 
8. Феофилова Е.П., Сергеева Я.Э., Ивашечкин А.А. (2010) Биодизельное топливо: состав, получение, продуценты, современная биотехнология (обзор). Прикладная биохимия и микробиология. 46: 405-415.

9. Abomohra A.E.-F., Wagner M., El-Sheekh M., Hanelt D. (2013) Lipid and total fatty acid productivity in photoautotrophic freshwater microalgae: screening studies towards biodiesel production J. Appl. Phycol. 25: 931-936.

10. Allen C., Watts K., Ackman R., Pegg M. (1999) Predicting the viscosity of biodiesel fuels from their fatty acid ester composition. Fuel. 78: 1319-1326.

11. Ameri M., Ghobadian B., Baratian I. (2008) Technical comparison of a CHP using various blends of gasohol in a IC engine. Renewable Energy. 33: 1469-1474.

12. Annadotter H., Cronberg G., Aagren R., Lundstedt B., Nilsson P.-A., Strobeck S. (1999) Multiple techniques for lake restoration. Hydrobiologia. 395/396: 77-85.

13. Atadashi I., Aroua M., Aziz A. (2011a) Biodiesel separation and purification: A review. Renewable Energy. 36: 437-443.

14. Atadashi I., Aroua M., Aziz A., Silaiman N. (2011b) Refining technologies for the purification of crude biodiesel. Applied Energy. 88: 4239-4251.

15. Balat M., Balat H., Oz C. (2008) Progress in bioethanol processing. Progress in Energy and Combustion Science. 34: 551-573.

16. Berrios M., Skelton R. (2008) Comparison of purification methods for biodiesel. Chemical Engineering Journal. 144: 459-465.

17. Bond T., Templeton M. (2011) History and future of domestic biogas plants in the developing world. Energy for Sustainable Development. 15: 347-354.

18. Cheng C., Lo Y., Lee K., Lee D., Lin C., Chang J. (2011) Biohydrogen production from lignocellulosic feedstock. Bioresour. Technol. 102: 8514-8523.

19. Chisti Y. (2007) Biodiesel from microalgae. Biotechnology Advances. 25: 294-306.

20. Christie W.W. (1993) Preparation of ester derivatives of fatty acids for chromatographic analysis. In: Advances in Lipid Methodology, 2d Ed. (Ed. W.W. Christie), Dundee: Oily Press, p. 69-111.

21. Day J.G., Slocombe S.P., Stanley M.S. (2012) Overcoming biological constraints to enable the exploitation of microalgae for biofuels. Bioresour. Technol. 109: 245-251.

22. Demirbas A. (2008) Biofuels sources, biofuel policy, biofuel economy and global biofuel projections. Energy Conversion and Management. 49: 2106-2116.

23. Demirbas A. (2009a) Biofuels securing the planet's future energy needs. Energy Conversion and Management. 50: 2239-2249.

24. Demirbas A. (2009b) Production of biodiesel from algae oils. Energy Sources. 31: 163-168.

25. Demirbas A. (2011) Competitive liquid biofuels from biomass. Applied Energy. 88: 17-28.

26. Demirbas A., Demirbas M.F. (2010) Algae energy. Algae as a new source of biodiesel. New York: Springer, $199 \mathrm{p}$.

27. Gerpen J. (2005) Biodiesel processing and production. Fuel Processing Technology. 86: 10971107.

28. Helwani Z., Othman M., Aziz N., Fernando W., Kim J. (2009) Technologies for production of biodiesel focusing on green catalytic techniques: A review. Fuel Processing Technology. 90: $1502-1514$. 
29. Huang G., Chen F., Wei D., Zhang X., Chen G. (2010) Biodiesel production by microalgae biotechnology. Applied Energy. 87: 38-46.

30. Jaruwat P., Kongjao S., Hunsom M. (2010) Management of biodiesel wastewater by the combined processes of chemical recovery and electrochemical treatment. Energy Conversion and Management. 51: 531-537.

31. Karmakar A., Karmakar S., Mukherjee S. (2010) Properties of various plants and animals feedstocks for biodiesel production. Bioresour. Technol. 101: 7201-7210.

32. Knothe G. (2005) Dependence of biodiesel fuel properties on the structure of fatty acid alkyl esters. Fuel Processing Technology. 86: 1059-1070.

33. Knothe G. (2007) Some aspects of biodiesel oxidative stability. Fuel Processing Technology 88: 669-677.

34. Knothe G. (2010) Biodiesel and renewable diesel: A comparison. Progress in Energy and Combustion Science. 36: 364-373.

35. Knothe G., Matheaus A., Ryan T. (2003) Cetane numbers of branched and straight-chain fatty esters determined in an ignition quality tester. Fuel. 82: 971-975.

36. Knothe G., Gerpen J.V., Krahl J. (2005) The Biodiesel Handbook. Illinois: AOCS Press; 302 p.

37. Kocar G., Civas N. (2013) An overview of biofuels from energy crops: Current status and future prospects. Renewable and Sustainable Energy Reviews. 28: 900-916.

38. Kuchkina A.Y., Gladyshev M.I., Sushchik N.N., Kravchuk E.S., Kalachova G.S. (2011) Biodiesel production from sediments of a eutrophic reservoir. Biomass and Bioenergy. 35: 2280-2284.

39. Kusdiana D., Saka S. (2004) Effects of water on biodiesel fuel production by supercritical methanol treatment. Bioresour. Technol. 91: 289-295.

40. Lam M., Lee K., Mohamed A. (2010) Homogeneous, heterogeneous and enzymatic catalysis for transesterification of high free fatty acid oil (waste cooking oil) to biodiesel: A review. Biotechnology Advances. 28: 500-518.

41. Lam M.K., Lee K.T. (2012) Microalgae biofuels: A critical review of issues, problems and the way forward. Biotechnology Advances. 30: 673-690.

42. Lapuerta M., Rodriguez-Fernandez J., Font de Mora E. (2009) Correlation for the estimation of the cetane number of biodiesel fuels and implications on the iodine number. Energy Policy. 37: 4337-4344.

43. Larsson S., Thyrel M., Geladi P., Lestander T. (2008) High quality biofuel pellet production from pre-compacted low density raw materials. Bioresour. Technol. 99: 7176-7182.

44. Leung D., Wu X., Leung M. (2010) A review on biodiesel production using catalyzed transesterification. Applied Energy. 87: 1083-1095.

45. Li Y., Chen Y.-F., Chen P., Min M., Zhou W., Martinez B., Zhu J., Ruan R. (2011) Characterization of a microalga Chlorella sp. well adapted to highly concentrated municipal wastewater for nutrient removal and biodiesel production. Bioresour. Technol. 102: 5138-5144.

46. Liang M.-H., Jiang J.-G. (2013) Advancing oleaginous microorganisms to produce lipid via metabolic engineering technology. Progress in Lipid Research. 52: 395-408.

47. Lu X., Vora H., Khosla C. (2008) Overproduction of free fatty acids in E. coli: Implications for biodiesel production. Metabolic Engineering. 10: 333-339. 
48. Miao X., Wu Q. (2006) Biodiesel production from heterotrophic microalgal oil. Bioresour. Technol. 97: 841-846.

49. Mondala A., Liang K., Toghiani H., Hernandez R., French T. (2009) Biodiesel production by in situ transesterification of municipal primary and secondary sludges. Bioresour. Technol. 100: 1203-1210.

50. Nigam P., Singh A. (2011) Production of liquid biofuels from renewable resources. Progress in Energy and Combustion Science. 37: 52-68.

51. Oner C., Altun S. (2009) Biodiesel production from inedible animal tallow and an experimental investigation of its use as alternative fuel in a direct injection diesel engine. Applied Energy. 86: 2114-2120.

52. Pousa G., Santos A., Suarez P. (2007) History and policy of biodiesel in Brazil. Energy Policy. 35: 5393-5398.

53. Ramos M., Fernandez C., Casas A., Rodriguez L., Perez A. (2009) Influence of fatty acid composition of raw materials on biodiesel properties. Bioresour. Technol. 100: 261-268.

54. REN21 (2013) Renewables 2013 global status report. Paris: REN21 Secretariat. http://www.ren21. net/REN21Activities/GlobalStatusReport.aspx

55. Ryu K. (2010) The characteristics of performance and exhaust emissions of a diesel engine using a biodiesel with antioxidants. Bioresour. Technol. 101: 578-582.

56. Sadeghinezhad E., Kazi S.N., Badarudin A., Oon C.S., Zubir M.N.M., Mehrali M. (2013) A comprehensive review of bio-diesel as alternative fuel for compression ignition engines. Renewable and Sustainable Energy Reviews. 28: 410-424.

57. Sawangkeaw R., Ngamprasertsith S. (2013) A review of lipid-based biomasses as feedstocks for biofuels production. Renewable and Sustainable Energy Reviews. 25: 97-108.

58. Show K., Lee D., Chang J. (2011) Bioreactor and process design for biohydrogen production. Bioresour. Technol. 102: 8524-8533.

59. Siddiquee M., Rohani S. (2011) Lipid extraction and biodiesel production from municipal sewage sludges: A review. Renewable and Sustainable Energy Reviews. 15: 1067-1072.

60. da Silva T.L., Gouveia L., Reis A. (2014) Integrated microbial processes for biofuels and high value-added products: the way to improve the cost effectiveness of biofuel production. Appl. Microbiol. Biotechnol. 98: 1043-1053.

61. Sushchik N.N., Kuchkina A.Y., Gladyshev M.I. (2013) Fatty acid content and composition of sediments from Siberian eutrophic water bodies: implications for biodiesel production. Water Research. 47: 3192-3200.

62. Stansell G.R., Gray V.M., Sym S.D. (2012) Microalgal fatty acid composition: implications for biodiesel quality. J. Appl. Phycol. 24: 791-801.

63. Tolmac D., Prulovic S., Lambic M., Radovanovic Lj., Tolmac J. (2014) Global trends on production and utilization of biodiesel. Energy Sources, Part B. 9: 130-139.

64. Tracking Clean Energy Progress (2013) IEA (International Energy Agency) publications. www. iea.org/publications/freepublications/publication/name,36773,en.html

65. Tran H.-L., Ryu Y.-J., Seong D.H., Lim S.-M., Lee C.-G. (2013) An effective acid catalyst for biodiesel production from impure raw feedstocks. Biotechnology and Bioprocess Engineering. 18: 242-247. 
66. Vicente G., Martinez M., Aracil J. (2004) Integrated biodiesel production: a comparison of different homogeneous catalysts systems. Bioresour. Technol. 92: 297-305.

67. Walekhwa P., Mugisha J., Drake L. (2009) Biogas energy from family-sized digesters in Uganda: Critical factors and policy implications. Energy Policy. 37: 2754-2762.

68. Walker D. (2009) Biofuels, facts, fantasy, and feasibility. J. Appl. Phycol. 21: 509-517.

69. Wassell C., Dittmer T. (2006) Are subsidies for biodiesel economically efficient? Energy Policy. 34: 3993-4001.

70. Wang J., Yang H., Wang F. (2014) Mixotrophic cultivation of microalgae for biodiesel production: status and prospects. Appl. Biochem. Biotechnol. 172: 3307-3329.

71. Wang Y., Ou S., Liu P., Zhang Z. (2007) Preparation of biodiesel from waste cooking oil via twostep catalyzed process. Energy Conversion and Management. 48: 184-188.

72. Wijffels R.H., Barbosa M.J. (2010) An outlook on microalgal biofuels. Science. 329: 796-799.

73. Xiao M., H.-J. Shin, Dong Q. Advances in cultivation and processing techniques for microalgal biodiesel: A review. Korean J. Chem. Eng. (2013) 30: 2119-2126

74. Xue J., Grift T., Hansen A. (2011) Effect of biodiesel on engine performance and emissions. Renewable and Sustainable Energy Reviews. 15: 1098-1116.

75. Yan Y., Li X., Wang G., Gui X., Li G., Su F., Wang X., Liu T. (2014) Biotechnological preparation of biodiesel and its high-valued derivatives: A review. Applied Energy. 113: 1614-1631.

76. Zhang Y., Dube M.A., McLean D.D., Kates M. (2003) Biodiesel production from waste cooking oil. 1. Progress design and technological assessment. Bioresour. Technol. 89: 1-16.

77. Zheng G., Wang L., Kang Z. (2010) Feasibility of biohydrogen production from tofu wastewater with glutamine auxotrophic mutant of Rhodobacter sphaeroides. Renewable Energy. 35: 29102913. 